\title{
PENGGUNAAN LABORATORIUM RIIL DAN VIRTUIL PADA PEMBELAJARAN FISIKA DENGAN MODEL INKUIRI TERBIMBING DITINJAU DARI KEMAMPUAN MATEMATIS DAN KETERAMPILAN BERPIKIR KRITIS
}

\author{
Matsun ${ }^{1}$ \\ Widha Sunarno ${ }^{2}$ \\ M. Masykuri ${ }^{3}$ \\ Pendidikan Fisika, Fakultas Pendidikan MIPA dan Teknologi, \\ IKIP PGRI Pontianak ${ }^{1}$ \\ Magister Pendidikan Sains, FKIP, Universitas Sebelas Maret ${ }^{2,3}$ \\ Email: matsun115@yahoo.com
}

\begin{abstract}
This research aims at finding out the differences and interaction of the implementation of teaching media, mathematical capability, and critical thinking towards the students' learning achievement. The method used in this research is experimental method. The population was all IV semester students of Physics Education Department of IKIP PGRI Pontianak in the academic year of 2015/2016. The writer used cluster random sampling to get the sample. Data analysis was done by using three ways anava varians analysis. Based on the data analysis, it can be concluded that: 1) there are differences of cognitive and affective learning achievement to the students who are taught by using guided inquiry model with real and virtual laboratory; 2) there are differences of students cognitive learning achievement with high and low mathematical capability; 3) there are differences to psychometric learning achievement to the students who have high and low critical thinking; 4) There is no interaction between Guided Inquiry Model using real and virual laboratory, high and low mathematical capability, and high and low critical thinking towards the students learning achievement.
\end{abstract}

Keywords: Guided inquiry model, real laboratory, virtual laboratory, mathematical capability, critical thinking.

\section{PENDAHULUAN}

Pembelajaran fisika di Perguruan Tinggi pada hakikatnya merupakan suatu proses untuk menghantarkan mahasiswa ke tujuan belajar yang ingin dicapai. Belajar fisika sebagai pengalaman oleh mahasiswa mengandung arti bahwa fisika 
Matsun, Widha. S., M. Masykuri - Penggunaan Laboratorium Riil ...

merupakan wahana untuk memahami mahasiswa bekerja dengan objekobjek konkret melalui kegiatan eksperimen sehingga mendapatkan pengetahuan. Melalui pembelajaran fisika diharapkan dapat menjadi wahana bagi mahasiswa untuk mempelajari diri sendiri, alam sekitarnya, dan prospek pengembangan lebih lanjut ke arah penerapannya dalam kehidupan sehari-hari. Keadaan yang terjadi di IKIP PGRI Pontianak, berdasarkan hasil pengamatan secara langsung menunjukkan bahwa proses pembelajaran fisika masih berpusat pada dosen dan dosen tersebut masih belum menerapkan model-model pembelajaran yang tepat, hanya berpusat pada model pembelajaran konvensional. Hal ini terlihat pada saat proses pembelajaran materi rangkaian seri RLC. Dosen mengawali pembelajaran dengan menginformasikan materi yang dipelajari kemudian menjelaskan. Aktivitas mahasiswa saat itu hanya mencatat dan mendengarkan saja, kurang adanya diskusi dalam proses pembelajaran, hanya mahasiswa sesekali bertanya dan menjawab konsep-konsep fisika yang menuntut pertanyaan yang diberikan. Sehingga proses pembelajaran dirasakan membosankan dan mahasiswa terlihat tidak aktif dan kurang termotivasi untuk dapat memahami materi yang telah diberikan.

Penilaian yang diberikan terhadap mahasiswa yang belajar melalui metode konvensional (ceramah, tanya jawab dan pemberian tugas), menunjukkan $56 \%$ mahasiswa yang memiliki prestasi belajar rendah (nilai < B) pada mata kuliah listrik magnet, sehingga IPK yang diperoleh mahasiswa yaitu rata-rata kurang dari tiga. Berdasarkan analisis soal-soal yang diberikan pada test tersebut, pada umumnya soal-soal tersebut dibuat untuk menguji kemampuan kognitif mahasiswa yang mencakup aspek pemahaman dan mengaplikasikan konsep. Hal ini menunjukkan bahwa pemahaman konsep fisika pada mahasiswa dapat dikatakan masih rendah dan masih belum memenuhi target. Rendahnya pemahaman konsep fisika pada mahasiswa diduga ada kaitannya dengan proses pembelajaran yang diterapkan masih belum meng- 
Matsun, Widha. S., M. Masykuri - Penggunaan Laboratorium Riil ...

gunakan model pembelajaran yang tepat dan inovatif. serta dipengaruhi oleh latar belakang mahasiswa sebelumnya. Sehingga berpengaruh terhadap rendahnya prestasi belajar mahasiswa.

Salah satu model pembelajaran yang dipandang dapat membantu dan memfasilitasi untuk memudahkan mahasiswa dalam menguasai konsep fisika dan berlatih mengembangkan kemampuan matematis dan keterampilan berpikir adalah inkuiri terbimbing. Penggunaan model inkuiri terbimbing dipilih karena melihat dari penelitian terdahulu yang telah dilakukan menunjukkan hasil yang baik. Pada penelitian yang dilakukan oleh Hussain dkk (2011) menunjukkan bahwa ada pengaruh yang signifikan antara pembelajaran menggunakan model inkuiri terbimbing dengan pembelajaran konvensional terhadap prestasi belajar. Pembelajaran dengan model inkuiri terbimbing dapat meningkatkan prestasi belajar siswa.

Unsur yang tidak kalah penting dalam kegiatan belajar mengajar adalah media pembelajaran. Media pembelajaran adalah alat bantu mengajar. Proses pengajaran pada hakekatnya menurut Hamdani (2011) adalah proses komunikasi, yaitu proses penyampaian pesan dari sumber pesan (pendidik) melalui media ke penerima pesan (peserta didik). Menjadi tugas dosen untuk memilih media pembelajaran yang memudahkan mahasiswa untuk memahami materi pelajaran. Kriteria pemilihan media pembelajaran, hendaknya dipilih sesuai kebutuhan dosen dan mahasiswa untuk membantu memperbaiki situasi belajar mengajar. Agar media yang dipilih memenuhi syarat sebagai sarana yang menunjang proses belajar mengajar, maka dosen harus mampu memilih dan menggunakan media pembelajaran yang tersedia maupun membuat inovasi-inovasi baru. Kriteria yang perlu dipertimbangkan dalam memilih media di kelas atau laboratorium diantaranya, kesesuiaan dengan tujuan belajar, materi, dan metode mengajar.

Laboratorium riil merupakan salah satu media yang bisa digunakan untuk proses belajar dan mengajar. Laboratorium riil adalah laboratorium yang didalamnya terdapat alat-alat 
Matsun, Widha. S., M. Masykuri - Penggunaan Laboratorium Riil ...

dan bahan-bahan riil yang digunakan untuk melakukan percobaan. Melakukan percobaan di laboratorium riil akan meningkatkan motivasi belajar mahasiswa dan menguatkan ingatan tentang materi yang dieksperimenkan.

Kegiatan praktik fisika dengan laboratorium virtuil dapat mengembangkan keterampilan proses sains. Pembelajaran sains dengan simulasi mengizinkan adanya interaksi antara mahasiswa dengan program simulasi. Mahasiswa dapat memodifikasi dan memanipulasi parameter-parameter sehingga menghasilkan konsekuensi tertentu yang diperlihatkan oleh program simulasi. Simulasi dapat mengembangkan keterampilan proses mahasiswa yaitu keterampilan untuk memanipulasi, menguji, mengeksplor, memprediksi, merumuskan pertanyaan, membangun hipotesis, mengumpulkan data dan mengobservasi, menganalisis serta memberi makna gejala fisis yang terjadi.

Faktor intrinsik dalam diri mahasiswa diantaranya kemampuan matematis dan keterampilan berpikir kritis diperlukan dalam pembelajaran fisika menggunakan laboratorium riil dan virtuil, disebabkan pada pembelajaran menggunakan laboratorium riil dan virtuil tersebut mahasiswa diharapkan menemukan sendiri konsep secara langsung melalui pengamatan.

Berpikir kritis menurut Starkety (2004) adalah suatu aktipitas kognitif yang berkaitan dengan penggunaan nalar, yang berarti menggunakan proses-proses mental, seperti memperhatikan, mengkategorikan, seleksi, dan menilai/memutuskan. Pola pikiran tinggi dibentuk berdasarkan cara berpikir kritis. Jadi pada pembelajaran dengan menggunakan laboratorium riil dan virtuil keterampilan berpikir kritis mahasiswa sangat diperlukan, karena pada pembelajaran menggunakan laboratorium riil dan virtuil, mahasiswa banyak memanfaatkan keterampilan berpikirnya.

Berdasarkan uraian yang dikemukan di atas, akan dilakukan penelitian penggunaan laboratorium riil dan virtuil pada pembelajaran fisika dengan model inkuiri terbimbing ditinjau dari kemampuan 
Matsun, Widha. S., M. Masykuri - Penggunaan Laboratorium Riil ...

matematis dan keterampilan berpikir kritis mahasiswa.

\section{METODE}

Populasi dalam penelitian ini adalah mahasiswa pendidikan fisika semester IV tahun pelajaran 2014/2015 yang terdiri dari 3 kelas dengan jumlah mahasiswa sebanyak 71 mahasiswa. Teknik pengambilan sampel dalam penelitian ini menggunakan teknik Cluster Random Sampling. Desain penelitian yang digunakan adalah penelitian eksperimen yang berusaha untuk mengetahui pengaruh antara suatu variabel terhadap variabel lainnya. Penelitian ini bersifat eksperimental dengan rancangan data penelitian disajikan dalam desain faktorial $2 \times 2 \times 2$ dengan teknik analisis varians (Anava).
Instrumen yang digunakan berupa silabus, SAP, LKM, dan intrumen pengambilan data berupa tes, angket dan lembar observasi. Instrumen bentuk tes untuk mengukur prestasi kognitif, kemampuan matematis, dan keterampilan berpikir kritis. Instrumen bentuk tes menggunakan tes pilihan ganda. Angket untuk mengukur prestasi afektif, sedangkan lembar observasi digunakan untuk mengukur prestasi afektif dan psikomotorik pada saat penelitian. Uji validasi intrumen dilakukan oleh ahli sebelum diuji cobakan. Setelah uji coba instrumen prestasi kognitif, kemampuan matematis, keterampilan berpikir kritis dan prestasi afektif diuji validitas dan reliabilitas soal. Prestasi kognitif dilanjutkan dengan uji taraf kesukaran dan uji daya pembeda soal.

Tabel 1. Hasil Uji Anava Prestasi Belajar Kognitif, Afektif, dan Psikomotorik

\begin{tabular}{lllll}
\hline No & Uji & $\begin{array}{l}\text { Sig. } \\
\text { Kognitif }\end{array}$ & Sig. Afektif & $\begin{array}{l}\text { Sig. } \\
\text { Psikomotor }\end{array}$ \\
\hline 1. & Hipotesis 1 & 0,001 & 0,03 & 0,85 \\
\hline 2. & Hipotesis 2 & 0,03 & 0,74 & 0,50 \\
\hline 3. & Hipotesis 3 & 0,33 & 0,61 & 0,00 \\
\hline 4. & Hipotesis 4 & 0,76 & 0,54 & 0,52 \\
\hline 5. & Hipotesis 5 & 0,04 & 0,48 & 0,03 \\
\hline 6. & Hipotesis 6 & 0,14 & 0,36 & 0,84 \\
\hline 7. & Hipotesis 7 & 0,63 & 0,74 & 0,31 \\
\hline
\end{tabular}


Matsun, Widha. S., M. Masykuri - Penggunaan Laboratorium Riil ...

\section{HASIL DAN PEMBAHASAN}

Data penelitian diuji menggunakan anava tiga jalan menggunakan program SPSS 18 dengan hasil seperti tabel 1.

1.Pengaruh pembelajaran dengan model inkuiri terbimbing menggunakan laboratorium riil dan laboratorium virtuil terhadap prestasi belajar kognitif, afektif, dan psikomotor mahasiswa.

Hasil uji hipotesis pada prestasi belajar kognitif menunjukkan signifikansi bernilai 0,001, prestasi belajar afektif menunjukkan signifikansi bernilai 0,038 , dan prestasi belajar psikomotor menunjukan signifikansi bernilai 0,854. Hal ini berarti terdapat pengaruh prestasi belajar kognitif dan afektif mahasiswa yang diberi pembelajaran dengan model inkuiri terbimbing menggunakan laboratorium riil dan laboratorium virtuil. Aspek psikomotor tidak terdapat pengaruh prestasi psikomotor mahasiswa yang diberi pembelajaran dengan model inkuiri terbimbing menggunakan laboratorium riil dan laboratorium virtuil.
Nilai rata-rata aspek kognitif pada kelas yang diberi pembelajaran dengan laboratorium riil adalah 59,70, sedangkan nilai rata-rata kelas yang diberi pembelajaran dengan laboratorium virtuil adalah 70,95. Hal ini sejalan dengan penelitian yang dilakukan oleh Georgiou, J dkk (2011). Kesimpulan dari hasil penelitian, diketahui bahwa mahasiswa yang diajar dengan menggunakan laboratorium virtuil memberikan prestasi lebih baik bagi mahasiswa. Simulasi memainkan peranan utama dalam pembelajaran tidak hanya menyediakan model yang realistis, mahasiswa juga dapat berinteraksi untuk mendapatkan pengalaman dunia nyata.

Pembelajaran inkuiri terbimbing menggunakan laboratorium virtuil untuk memahami materi rangkaian seri RLC secara teoritis memiliki beberapa kelebihan dibandingkan dengan pembelajaran inkuiri terbimbing menggunakan laboratorium riil hal ini sesuai dengan penelitian yang dilakukan oleh Dobrzanski, L.A (2011) Laboratorim virtuil dapat 
Matsun, Widha. S., M. Masykuri - Penggunaan Laboratorium Riil ...

digunakakan secara praktis, murah dan mudah. Mahasiswa dapat mengulangi percobaan dengan mudah baik di kampus maupun di rumah, dan adanya animasi membuat mahasiswa lebih termotivasi dalam belajar, serta harga laboratorium virtuil lebih murah dibandingkan dengan alatalat laboratorium riil.

Terdapat pengaruh yang signifikan hasil prestasi belajar kognitif dari uji statistik hal ini dikarenakan ada beberapa faktor yang mempengaruhi hasil penelitian. Hasil pengamatan faktor pertama yaitu pengaruh proses pembelajaran, kelas yang menggunakan laboratorium virtuil mayoritas mahasiswa berperan aktif untuk membangun pengetahuan yang didapat dari simulasi yang diamati, sehingga membuat pembelajaran pada materi rangkaian seri RLC menjadi lebih jelas dan konkret, faktor yang kedua, mahasiswa yang menggunakan laboratorium riil proses asimilasi, akomodasi, dan ekuilibrasi tidak dapat berjalan secara maksimal, hal ini disebabkan lamanya kegiatan praktikum sehingga berdampak terhadap terbatasnya waktu dosen untuk menyampaikan konsep dari materi yang diajarkan. Mahasiswa kurang maksimal dalam menerimana konsep materi karena hanya melihat dan melakukan praktikum tanpa disertai penjelasan yang lebih detail dari dosen.

Nilai rata-rata prestasi belajar afektif pada kelas yang diberi pembelajaran dengan laboratorium riil adalah 92,40 sedangkan nilai rata-rata kelas yang diberi pembelajaran dengan laboratorium virtuil adalah 95,91. Data tersebut menunjukkan bahwa pembelajaran fisika menggunakan laboratorium virtuil lebih baik dalam meningkatkan prestasi belajar afektif mahasiswa dibanding kelas yang menggunakan laboratorium riil. Hal ini sejalan dengan penelitian yang dilakukan Cengiz Tuysuz (2010) dari hasil penelitian dapat disimpulkan bahwa laboratorium virtuil memberikan efek positif terhadap prestasi dan sikap mahasiswa bila 
Matsun, Widha. S., M. Masykuri - Penggunaan Laboratorium Riil ...

dibandingkan dengan menggunakan media laboratorium riil. Apabila ditinjau dari lembar observasi prestasi belajar afektif, yang meliputi: kemauan untuk menerima pelajaran, memperhatikan terhadap penjelasan dosen, keinginan untuk bertanya, kemauan untuk mempelajari bahan pelajaran lebih lanjut, kemauan untuk menerapkan hasil pelajaran, teliti dalam pengamatan, jujur dalam pengambilan data, dan bekerjasama dengan baik. Penggunaan laboratorium virtuil akan mempengaruhi prestasi belajar afektif lebih didominasi oleh faktor internal mahasiswa, yang dijabarkan dengan berbagai aktivitas dan persiapan diri mahasiswa untuk menghadapi materi yang akan disampaikan saat di rumah atau di luar jam kuliah. Sebagai contoh, mahasiswa yang mengulang kembali pelajaran menggunakan laboratorium virtuil, memperdalam materi melalui media virtuil yang sudah dimiliki akan lebih mudah dibandingkan dengan laboratorium riil. Hal ini sejalan dengan penelitian yang dilakukan oleh Burd Stephen

(2010) bahwa penggunaan laboratorium virtuil dapat digunakan baik di dalam kelas atau di luar kelas.

2. Pengaruh prestasi belajar kognitif, afektif, dan psikomotor mahasiswa yang memiliki kemampuan matematis tinggi dan rendah.

Hasil uji hipotesis pada prestasi belajar kognitif menunjukkan signifikansi bernilai 0,039, prestasi belajar afektif menunjukkan signifikansi bernilai 0,743 , dan prestasi belajar psikomotor menunjukan signifikansi bernilai 0,501. Hal ini berarti terdapat pengaruh prestasi belajar kognitif mahasiswa yang memiliki kemampuan matematis tinggi dan rendah, sedangkan pada aspek afektif dan psikomotor tidak terdapat pengaruh prestasi belajar mahasiswa yang memiliki kemampuan matematis tinggi dan rendah.

Nilai rata-rata kemampuan matematis tinggi pada aspek kognitif adalah 68,63 sedangkan nilai rata-rata kemampuan matematis rendah adalah 62,02. 
Matsun, Widha. S., M. Masykuri - Penggunaan Laboratorium Riil ...

Berdasarkan mahasiswa yang

memiliki kemampuan matematis

kategori tinggi mendapat nilai rata-

rata kognitif lebih besar daripada

mahasiswa yang memiliki

kemampuan matematis kategori

rendah, jadi mahasiswa yang

memiliki kemampuan matematis

tinggi lebih besar pengaruhnya

terhadap prestasi belajar kognitif.

Hal ini disebabkan karena dalam

materi rangkaian seri RLC

merupakan kompleksitasnya tinggi

dan memuat konsep matematis

yang cukup banyak, maka

diperlukan kemampuan matema-

tika yang cukup tinggi. Hal ini

sejalan dengan penelitian yang

dilakukan Salpan (2012) bahwa

dalam fisika, matematika

memegang peran utama. Selain

kemampuannya untuk me-

mecahkan problem fisika dari yang

sederhana sampai yang lebih

rumit, matematika sangat

membantu penalaran seseorang

dalam menyelusuri liku-liku fisika

yang ternyata memerlukan

penalaran cukup tinggi.

Kemampuan matematis merupakan faktor internal mahasiswa.
Ternyata mahasiswa yang

memiliki kemampuan matematis tinggi memiliki rata-rata nilai afektif dan psikomotor yang tidak jauh berbeda dengan rata-rata nilai afektif dan psikomotor mahasiswa yang memiliki kemampuan matematis rendah. Pengaruh prestasi belajar kognitif, afektif, dan psikomotor mahasiswa yang memiliki keterampilan berpikir kritis tinggi dan rendah.

Hasil uji hipotesis pada prestasi belajar kognitif menunjukkan signifikansi bernilai 0,332, prestasi belajar afektif menunjukkan signifikansi bernilai 0,617 , dan prestasi belajar psikomotor menunjukan signifikansi bernilai 0,000. Hal ini berarti tidak terdapat pengaruh prestasi belajar kognitif dan afektif pada mahasiswa yang memiliki keterampilan berpikir kritis tinggi dan rendah. Aspek psikomotor terdapat pengaruh prestasi belajar psikomotor mahasiswa yang memiliki keterampilan berpikir kritis tinggi dan rendah.

Keterampilan berpikir kritis merupakan usaha mengaplikasikan 
Matsun, Widha. S., M. Masykuri - Penggunaan Laboratorium Riil ...

rasional, kegiatan berpikir yang tinggi, yang meliputi kegiatan menganalisis, mensisntesis, mengenal permasalahan dan pemecahan, menyimpulkan, dan mengevaluasi. Berpikir kritis merupakan aspek penting yang harus dimiliki mahasiswa baik dalam pembelajaran maupun kehidupan sosial. Keterampilan berpikir kritis berkaitan erat dengan kemampuan seseorang dalam keterbukaan pikiran dalam menghadapai berbagai kejadian atau peristiwa. Pada materi rangkaian seri RLC, suatu hal yang sangat penting dalam memahami dan menerapkan konsep-konsep adalah kemampuan mahasiswa dalam menganalisis suatu perestiwa atau kejadian berdasarkan logika atau penalaran, bukan berdasarkan pada keterbukaan pikiran dalam menghadapi sesuatu dengan memperhitungkan berbagai alasan, baik alasan dari diri sendiri maupun dari orang lain.

Pada aspek psikomotor, nilai rata-rata keterampilan berpikir kritis tinggi adalah 74,43 sedangkan nilai rata-rata keterampilan berpikir kritis rendah adalah 65,70. Berpikir kritis yang dikemukakan oleh Wrihgt Place Consulting dalam Roy dan Sandra (2007) yaitu berpikir kritis merupakan proses yang bermuara pada tujuan akhir berupa kesimpulan atau keputusan yang masuk akal tentang apa yang harus percayai dan tindakan apa yang dilakukan. Meskipun demikian, berpikir kritis dilakukan bukan hanya untuk mencari jawaban semata melainkan mempertanyakan jawaban. Fakta, atau informasi yang ada. Dengan demikian dapat ditemukan alternatif atau solusi terbaiknya. Seseorang yang memiliki keterampilan berpikir kritis tinggi akan berupaya untuk memecahkan masalah yang dihadapi dengan berbagai cara dan memilih cara mana yang paling tepat untuk memperoleh penyelesaian. Hal ini tampak dari hasil prestasi belajar psikomotor mahasiswa dengan keterampilan berpikir kritis tinggi yang nilainya lebih baik 
Matsun, Widha. S., M. Masykuri - Penggunaan Laboratorium Riil ...

dibandingkan mahasiswa dengan keterampilan berpikir kritis rendah.

3. Interaksi antara media laboratorium riil dan virtuil dengan kemampuan matematis terhadap prestasi belajar mahasiswa.

Hasil uji hipotesis pada prestasi belajar kognitif menunjukkan signifikansi bernilai 0,769, prestasi belajar afektif menunjukkan signifikansi bernilai 0,541 , dan prestasi belajar psikomotor menunjukan signifikansi bernilai 0,524. Hal ini berarti interaksi antara media laboratorium riil dan virtuil dengan kemampuan matematis tidak memberikan pengaruh signifikan terhadap prestasi belajar kognitif, afektif dan psikomotor mahasiswa.

Dahar (1989: 151) Jean Peaget menyatakan bahwa pembelajaran lebih berhasil apabila disesuaikan dengan tahap perkembangan kognitif peserta didik. Dengan demikian, dosen dapat memberikan perlakuan yang tepat bagi mahasiswanya. Dalam penelitian ini melalui media menggunakan laboratorium riil maupun virtuil, berdasarkan hasil pengujian hipotesis kognitif, afektif dan psikomotor, bahwa tingkat kemampuan matematis dan media pembelajaran mempunyai pengaruh sama terhadap prestasi belajar kognitif, afektif dan psikomotor mahasiswa.

4. Interaksi antara media laboratorium riil dan virtuil dengan keterampilan berpikir kritis terhadap prestasi belajar mahasiswa.

Hasil uji hipotesis pada prestasi belajar kognitif menunjukkan signifikansi bernilai 0,04 , prestasi belajar afektif menunjukkan signifikansi bernilai 0,48 , dan prestasi belajar psikomotor menunjukan signifikansi bernilai 0,03. Hal ini berarti bahwa interaksi antara media laboratorium riil dan virtuil dengan keterampilan berpikir kritis memberikan pengaruh signifikan terhadap prestasi belajar kognitif dan psikomotor mahasiswa, sedangkan pada aspek afektif, interaksi antara media laboratorium riil dan virtuil dengan keterampilan berpikir kritis tidak memberikan pengaruh signifikan 
Matsun, Widha. S., M. Masykuri - Penggunaan Laboratorium Riil ...

terhadap prestasi belajar afektif mahasiswa.

Penggunaan laboratorium riil dan virtuil pada mahasiswa yang mempunyai keterampilan berpikir kritis tinggi memperoleh prestasi kognitif dan psikomotor lebih tinggi dibanding mahasiswa yang memiliki keterampilan berpikir kritis rendah. Hal ini sejalan dengan penelitian yang dilakukan oleh Haseli dan Razeii (2013), yang menyatakan bahwa proses pembelajaran yang menekankan pada pengembangan keterampilan berpikir kritis akan meningkatkan prestasi belajar secara signifikan. Mahasiswa yang memiliki keterampilan berpikir kritis tinggi akan memperoleh prestasi belajar lebih baik.

Mahasiswa yang mempunyai keterampilan berpikir kritis rendah dapat mengikuti pembelajaran rangkaian seri RLC bila diajar dengan model inkuiri terbimbing melalui laboratorium riil. Media laboratorium riil memberi gambaran yang jelas tentang karakteristik rangkaian RLC. Hal ini terlihat pada saat mahasiswa melakukan praktikum, mahasiswa terlihat antusias dan senang dalam melakukan praktikum sendiri. Mahasiswa yang diberi model inkuiri terbimbing melalui laboratorium virtuil, mahasiswa yang mempunyai keterampilan berpikir kritis rendah mengalami banyak kesulitan dalam mengoperasikan, memahami informasi yang diberikan komputer. Hal ini dapat dilihat pada hasil uji lanjut anava terjadi interaksi pada kelompok mahasiswa yang memiliki keterampilan berpikir kritis rendah jika diberi pembelajaran menggunakan laboratorium riil dibandingkan dengan mahasiswa yang mempunyai keterampilan berpikir kritis rendah jika diberi pembelajaran menggunakan laboratorium virtuil memberikan pengaruh yang signifikan terhadap prestasi belajar kognitif maupun psikomotor.

5. Interaksi antara kemampuan matematis dan keterampilan berpikir kritis.

Hasil uji hipotesis pada prestasi belajar kognitif menunjukkan 
Matsun, Widha. S., M. Masykuri - Penggunaan Laboratorium Riil ...

signifikansi bernilai 0,14 , prestasi belajar afektif menunjukkan signifikansi bernilai 0,36 , dan prestasi belajar psikomotor menunjukan signifikansi bernilai 0,84. Hal ini berarti bahwa interaksi antara kemempauan matematis dan keterampilan berpikir kritis tidak memberikan pengaruh signifikan terhadap prestasi belajar kognitif, efektif, dan psikomotor mahasiswa.

Tidak adanya interaksi antara kemampuan matematis dan keterampilan berpikir kritis terhadap prestasi belajar kognitif, afektif dan psikomotor disebabkan mahasiswa yang memiliki kemampuan matematis dan keterampilan berpikir kritis tinggi dalam proses pembelajaran lebih aktif, lebih inisiatif dan memiliki rasa percaya diri yang tinggi, sedangkan mahasiswa yang memiliki kemampuan matematis dan keterampilan berpikir kritis rendah cendrung bersifat pasif, takut atau malu-malu dan lebih sering bertanya kepada temantemanya untuk bisa memahami suatu konsep.
6. Interaksi antara media laboratorium riil dan virtuil dengan kemampuan matematis dan keterampilan berpikir kritis terhadap prestasi belajar kognitif, afektif, dan psikomotor.

Hasil uji hipotesis pada prestasi belajar kognitif menunjukkan signifikansi bernilai 0,637, prestasi belajar afektif menunjukkan signifikansi bernilai 0,743 , dan prestasi belajar psikomotor menunjukan signifikansi bernilai 0,317. Berdasarkan keputusan uji maka hipotesis nol diterima pada aspek kognitif, afektif, dan psikomotor. Hal ini berarti interaksi antara media laboratorium riil dan virtuil, kemampuan matematis dan keterampilan berpikir kritis tidak memberikan pengaruh signifikan terhadap prestasi belajar kognitif, afektif dan psikomotor mahasiswa.

Dapat dipahami bahwa pembelajaran menggunakan laboratorium riil dan virtuil pada mahasiswa dengan kemampuan matematis dan keterampilan berpikir kritis tinggi menghasilkan rerata prestasi belajar yang lebih 
Matsun, Widha. S., M. Masykuri - Penggunaan Laboratorium Riil ...

baik daripada mahasiswa dengan kemampuan matematis dan keterampilan berpikir kritis rendah. Pembelajaran menggunakan laboratorium riil dan virtuil pada mahasiswa dengan kemampuan matematis dan keterampilan berpikir kritis tidak berinteraksi terhadap prestasi belajar kognitif, afektif dan psikomotor dikarenakan teknik pembelajaran dengan laboratorium riil dan virtuil yang digunakan dalam proses pembelajaran tidak akan berpengaruh optimal jika tidak didukung oleh kemampuan matematis dan keterampilan berpikir kritis cukup.

\section{PENUTUP}

\section{Kesimpulan}

Hasil penelitian ini dapat disimpulkan bahwa: 1) Pembelajaran dengan model inkuiri terbimbing menggunakan laboratorium virtuil lebih baik dalam meningkatkan prestasi belajar kognitif dan afektif mahasiswa dibanding kelas yang menggunakan laboratorium riil. Prestasi belajar psikomotor mahasiswa menggunakan labo- ratorium riil dan virtuil memberikan hasil yang sama; 2) Ada pengaruh prestasi belajar kognitif bagi mahasiswa yang memiliki kemampuan matematis tinggi dan rendah, sedangkan pada aspek afektif dan psikomotor tidak terdapat pengaruh prestasi belajar mahasiswa. Mahasiswa yang memiliki kemampuan matematis tinggi lebih besar pengaruhnya terhadap prestasi belajar kognitif. Prestasi belajar afektif yang dinilai hanyalah sikap. Begitu pula dengan prestasi belajar psikomotor yang dinilai hanyalah keaktifan melakukan percobaan; 3) Tidak ada pengaruh prestasi belajar kognitif dan afektif bagi mahasiswa yang memiliki keterampilan berpikir kritis tinggi dan rendah, sedangkan pada aspek psikomotor terdapat pengaruh prestasi belajar mahasiswa. Seseorang yang memiliki keterampilan berpikir kritis tinggi akan berupaya untuk memecahkan masalah yang dihadapi dengan berbagai cara dan memilih cara mana yang paling tepat untuk memperoleh penyelesaian. Hal ini tampak dari hasil prestasi belajar psikomotor mahasiswa dengan keterampilan 
Matsun, Widha. S., M. Masykuri - Penggunaan Laboratorium Riil ...

berpikir kritis tinggi yang nilainya lebih baik dibandingkan mahasiswa dengan keterampilan berpikir kritis rendah; 4) Tidak ada interaksi antara media pembelajaran laboratorium riil dan virtuil dengan kemampuan matematis terhadap prestasi belajar kognitif, afektif dan psikomotor mahasiswa; 5) Ada interaksi antara media pembelajaran laboratorium riil dan virtuil dengan keterampilan berpikir kritis terhadap prestasi belajar kognitif dan psikmotor mahasiswa, sedangkan pada aspek afektif tidak terdapat interaksi; 6) Tidak ada interaksi antara kemampuan matematis dan keterampilan berpikir kritis terhadap prestasi belajar kognitif, afektif, dan psikomotor mahasiswa; 7) Tidak ada interaksi antara media laboratorium riil dan virtuil, kemampuan matematis dan keterampilan berpikir kritis terhadap prestasi belajar kognitif, afektif dan psikomotor mahasiswa.

\section{DAFTAR PUSTAKA}

Burd, Stephen D, and Seazzu, Alessandro F. (2010). Virtual computing laboratories: A Case Study With Comparisons To Physical Computing Laborataries.
Journal of Information Technology Education, Vol 8, 55-78.

Cangiz Tuysuz. (2010). The Effect of the Virtual Laboratory on Student's Achievement and Attitude in Chemistry. International Online Journal of Educational Sciences, vol 2 (1), 37-53.

Dahar, RW. 1989. Teori-teori belajar. Jakarta: Erlangga.

Dobrzanski, L. A, and Honysz, R. (2011). Material Science Virtual Laboratory As An Example Of The Computer Aid In Material Engineering. Jamme, Vol 24, 219222.

Georgiou, J, Dimitropoulos, K, and Manitsaris. (2011). A Virtual Reality Laboratory for Distance Education in Chemistry. Internasional Journal Of Social Science. Vol.2, 78-87.

Hamdani. 2011. Strategi Belajar Mengajar. Bandung: Pustaka Setia.

Haseli, Z, dan Razeii, F. (2013). The Effect of Teaching Critical thinking on Educational Achievement and Test Anxiety among Junior High School Students in Saveh. European. J. Nat. Soc. Scie, 2 (2), 168-175.

Hussain, A, Azem, M, dan Shakoor, A. (2011). Physics Teaching Methods: Scientific Inquiry Vs Traditional Lecture. Pakistan. In. J. Hum. Sos. Sci, 1 (19), 269-276.

Roy S. Dan Sandra S. (2007). Apakah Anda sudah Berpikir Kritis? (Online), (http://www. sinarharapan.co.id/berita/0612/19/e ko07.html diakses tanggal 18 April 2013).

Salpan. (2012). Pembelajaran Fisika Dengan Metode Demontrasi Menggunakan Alat Peraga dan 
Matsun, Widha. S., M. Masykuri - Penggunaan Laboratorium Riil ...

Media Interaktif Berbasis

Komputer Ditinjau Dari Tingkat

Berpikir Abstrak dan Kemampuan

Matematika. Tesis. Surakarta:

Universitas Sebelas Maret

Surakarta.

Starkety, L. (2004). Critikal Thinking

skills Success in 20 minutes A

Day. New York : Learning

Express. 